Review

\title{
Some Special Aircraft
}

\author{
${ }^{1}$ Relly Victoria Petrescu, ${ }^{2}$ Raffaella Aversa, ${ }^{3}$ Bilal Akash, ${ }^{4}$ Juan Corchado, \\ ${ }^{2}$ Antonio Apicella and ${ }^{1}$ Florian Ion Tiberiu Petrescu \\ ${ }^{I}$ ARoTMM-IFToMM, Bucharest Polytechnic University, Bucharest, (CE), Romania \\ ${ }^{2}$ Advanced Material Lab, Department of Architecture and Industrial Design, \\ Second University of Naples, 81031 Aversa (CE), Italy \\ ${ }^{3}$ Dean of School of Graduate Studies and Research, American University of Ras Al Khaimah, UAE \\ ${ }^{4}$ University of Salamanca, Spain
}

Article history

Received: 10-07-2017

Revised: $10-08-2017$

Accepted: 18-08-2017

Corresponding Author: Florian Ion Tiberiu Petrescu ARoTMM-IFToMM, Bucharest Polytechnic University, Bucharest, (CE), Romania E-mail: scipub02@gmail.com
Abstract: In this study, the authors want to present a few more distinct aircraft from a constructive and functional point of view. Their role has often been determined by the need to achieve or fulfill certain more or less strategic objectives. Such ships will also be built in the future more and more often in order to be able to respond to all new flight requirements and to meet, under optimal conditions, the new and increasingly demanding requirements. Many of the new special aircraft have been built so far to achieve special tasks, or at the request of the defense ministry in some highly developed countries, even with the United States of America. The PA-23 was the first twin-engine design from Piper and was developed from a proposed "Twin Stinson" design inherited when Piper bought the Stinson Division of the Consolidated Vultee Aircraft Corporation. The prototype PA-23 was a four-seater low-wing all-metal monoplane with a twin tail, powered by a two $125 \mathrm{hp}$ Lycoming O-290-D piston engines the prototype first flew 2 March 1952. The aircraft performed badly and it was redesigned with a single vertical stabilizer and an all-metal rear fuselage and more powerful $150 \mathrm{hp}$ Lycoming O-320-A engines. Two new prototypes of re-designed aircraft now named Apache were built in 1953 and entered production in 1954; 1,231 were built. In 1958, the Apache 160 was produced by upgrading the engines to $160 \mathrm{hp}(119 \mathrm{~kW})$ and 816 were built before being superseded by the Apache 235, which went to $235 \mathrm{hp}$ (175 kW) engines and swept tail surfaces (119 built). In 1958 an upgraded version with $250 \mathrm{hp}(186 \mathrm{~kW})$ Lycoming O-540 engines and adding a swept vertical tail was produced as the PA-23-250 and was named Aztec. These first models came in a five-seat configuration which became available in 1959. In 1961 a longer nosed variant the Aztec B entered production. The later models of the Aztec were equipped with IO-540 fuel injected engines and six-seat capacity and continued in production until 1982. There were also turbocharged versions of the later models, which were able to fly at higher altitudes. The US Navy acquired 20 Aztecs, designating them UO-1, which changed to U-11A when unified designations were adopted in 1962. In 1974, Piper produced a single experimental PA-41P Pressurized Aztec concept.

Keywords: Some Special Aircraf, Helicopters, Aerospace, Spacecraft Propulsion, US Army, Jet Engines, Spirit Strategic Bomber, Defense Contractor

\section{Introduction}

In this study, the authors want to present a few more distinct aircraft from a constructive and functional point of view.
Their role has often been determined by the need to achieve or fulfill certain more or less strategic objectives.

Such ships will also be built in the future more and more often in order to be able to respond to all new flight requirements and to meet, under optimal 
conditions, the new and increasingly demanding requirements (Aversa et al., 2016a; 2016b; 2016c; 2016d; 2016e; 2016f; 2016g; 2016h; 2016i; 2016j; 2016k; 2016l; 2016m; 2016n; 2016o; 2017a; 2017b; 2017c; 2017d; 2017e).

Many of the new special aircraft have been built so far to achieve special tasks, or at the request of the defense ministry in some highly developed countries, even with the United States of America (Mirsayar et al., 2017).

\section{Materials and Methods}

The PA-23 was the first twin-engine design from Piper and was developed from a proposed "Twin Stinson" design inherited when Piper bought the Stinson Division of the Consolidated Vultee Aircraft Corporation (Fig. 1).

The prototype PA-23 was a four-seater low-wing allmetal monoplane with a twin tail, powered by a two 125 hp Lycoming O-290-D piston engines the prototype first flew 2 March 1952. The aircraft performed badly and it was redesigned with a single vertical stabilizer and an all-metal rear fuselage and more powerful $150 \mathrm{hp}$ Lycoming O-320-A engines.

Two new prototypes of re-designed aircraft now named Apache were built in 1953 and entered production in 1954; 1,231 were built. In 1958, the Apache 160 was produced by upgrading the engines to $160 \mathrm{hp}(119 \mathrm{~kW})$ and 816 were built before being superseded by the Apache 235, which went to $235 \mathrm{hp}$ $(175 \mathrm{~kW})$ engines and swept tail surfaces (119 built).

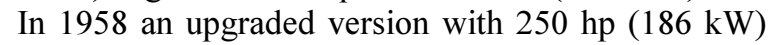
Lycoming O-540 engines and adding a swept vertical tail was produced as the PA-23-250 and was named Aztec. These first models came in a five-seat configuration which became available in 1959 .

In 1961 a longer nosed variant the Aztec B entered production. The later models of the Aztec were equipped with IO-540 fuel injected engines and six-seat capacity and continued in production until 1982. There were also turbocharged versions of the later models, which were able to fly at higher altitudes (Petrescu and Petrescu, 2009; 2011; 2012a; 2012b; 2013a; 2013b; 2013c).

The US Navy acquired 20 Aztecs, designating them UO-1, which changed to U-11A when unified designations were adopted in 1962.

In 1974, Piper produced a single experimental PA-41P Pressurized Aztec concept. This concept was short-lived, however, as the aspects of the Aztec that made it so popular for its spacious interior and ability to haul large loads did not lend themselves well to supporting the sealed pressure vessel required for a pressurized aircraft.

The project was scrapped and the one pressurized Aztec produced, N9941P, was donated to Mississippi State University, where it was used for testing purposes. In 2000, N9941P was donated to the Piper Aviation Museum in Lock Haven, PA, on the condition that it never be flown again. It now sits there on display.
The DHC-6 Twin Otter is a Canadian 19-passenger Short Takeoff and Landing (STOL) utility aircraft developed by de Havilland Canada and currently produced by Viking Air.

The aircraft's fixed tricycle undercarriage, STOL abilities and high rate of climb have made it a successful cargo, regional passenger airliner and MEDEVAC aircraft. In addition, the Twin Otter has been popular with commercial skydiving operations and it is used by the United States Army Parachute Team (Fig. 2).

Development of the aircraft began in 1964, with the first flight on May 20, 1965.

A twin-engined replacement for the single-engined Otter had been planned by de Havilland Canada. Twin engines not only provided improved safety but also allowed for an increase in payload while retaining the renowned STOL qualities.

Design features included double slotted trailing edge flaps and ailerons that work in unison with the flaps to boost STOL performance.

The availability of the $550 \mathrm{shp}(410 \mathrm{~kW})$ Pratt and Whitney Canada PT6A-20 propeller turbine engine in the early 1960s made the concept of a twin more feasible.

To bush operators, the improved reliability of turboprop power and the improved performance of a twin-engined configuration made it an immediately popular alternative to the single engine, piston-powered Otter which had been flying since 1951.

The first six aircraft produced were designated Series 1 , indicating that they were prototype aircraft.

The initial production run consisted of Series 100 aircraft, serial number seven to 115 inclusive.

In 1968, Series 200 production began with serial number 116.

Changes made at the beginning of Series 200 production included improving the STOL performance, adding a longer nose that was equipped with a larger baggage compartment (except to aircraft fitted with floats) and fitting a larger door to the rear baggage compartment.

All Series 1, 100 and 200 aircraft and their variants $(110,210)$ were fitted with the 550 shaft horsepower PT6A-20 engines.

In 1969, the Series 300 was introduced, beginning with serial number 231 .

Both aircraft performance and payload were improved by fitting more powerful PT6A-27 engines. This was a $680 \mathrm{hp}(510 \mathrm{~kW})$ engine that was flat-rated to $620 \mathrm{hp} \mathrm{(460}$ $\mathrm{kW}$ ) for use in the Series 300 Twin Otter. The Series 300 proved to be the most successful variant by far, with 614 Series 300 aircraft and their sub-variants (Series 310 for United Kingdom operators, Series 320 for Australian operators, etc.) sold before production ended in 1988.

After Series 300 production ended, the remaining tooling was purchased by Viking Air of Victoria, British Columbia, who manufacture replacement parts for all of the out of production de Havilland Canada aircraft. 


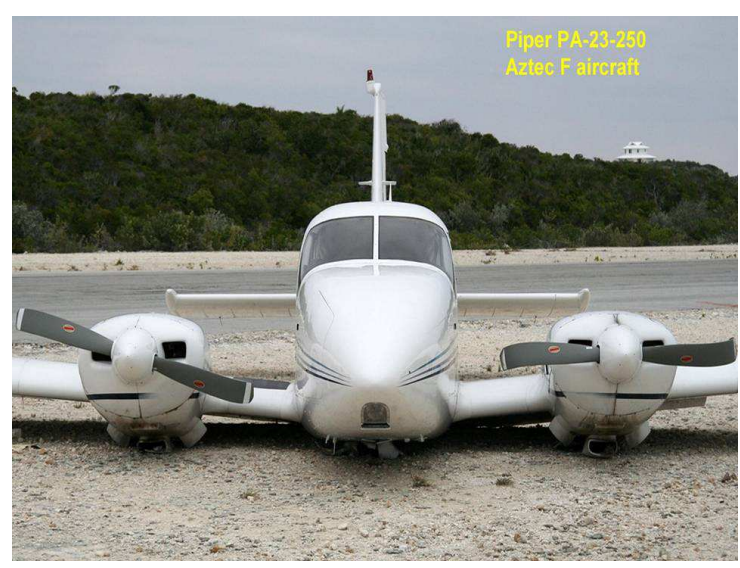

Fig. 1. The piper PA-23-250 aztec F aircraft. Source: Petrescu and Petrescu (2011)

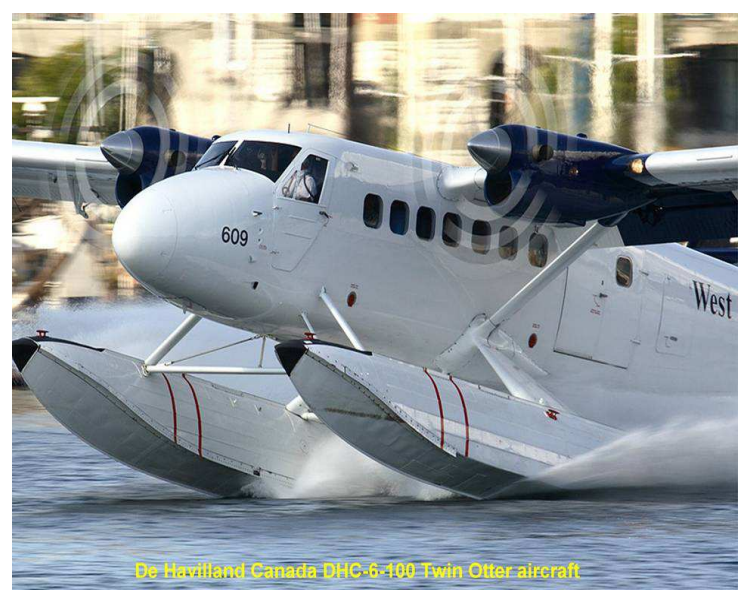

Fig. 2. De Havilland Canada DHC-6-100 Twin Otter aircraft. Source: Petrescu and Petrescu (2011)

On February 24, 2006, Viking purchased the type certificates from Bombardier Aerospace for all the out of production de Havilland DHC-1 through DHC-7 aircraft. The ownership of the certificates gives Viking the exclusive right to manufacture new aircraft.

On July 17, 2006, at the Farnborough Air Show, Viking Air announced its intention to offer a Series 400 Twin Otter. On April 2, 2007, Viking announced that with 27 orders and options in hand, it was restarting production of the Twin Otter, equipped with a more powerful Pratt \& Whitney Canada PT6A-34/35 engine. As of November 2007, 40 firm orders and 10 options had been taken and a new assembly plant established in Calgary, Alberta. Zimex Aviation of Switzerland received the first new production aircraft, serial number 845, in July 2010.

Major changes introduced with the Series 400 include Honeywell Primus Apex fully integrated avionics, deletion of the AC electrical system, deletion of the beta backup system, modernization of the electrical and lighting system and use of composites for non-loadbearing structures such as doors.

The Edgley EA-7 Optica (Fig. 3) was a British light aircraft designed for observation work, intended as a low-cost alternative to helicopters, retailing originally at around US\$200,000.

The Optica, designed by John Edgley and built by Brook lands Aerospace, had an unusual configuration with a fully-glazed forward cabin seating three across, reminiscent of an Alouette helicopter.

Behind it was situated a Lycoming flat-six engine powering a ducted fan, twin boom cantilever tailplane with twin rudders and a high-mounted single elevator. The fixed tricycle undercarriage had the nose wheel offset to the left.

The wings were unswept and untapered and the aircraft was of a fairly standard all-metal construction with stressed aluminum skin.

The aircraft's distinctive appearance led to it being known as the "bug-eye" in some popular reports.

It first flew on 14 December 1979 , powered by a 150 hp (112 kW) Lycoming O-320 engine and flown by the chief pilot of the Cranfield College of Aeronautics.

The Optica, now powered by a more powerful Lycoming O-540, entered production in 1983, achieving certification on 8 February 1985.

A crash of police Optica G-KATY on 15 May 1985 killed two members of the Hampshire Constabulary.

The cause was suspected to be a stall: Insufficient airspeed during a turn causing instability.

The reason for the low speed was never established. This led to the bankruptcy of Edgley, with Optica Industries being formed in October 1985 to continue production and 25 were built before a fire caused by arson destroyed the factory and all but one flying Optica.

The company was reformed again as Brooklands Aircraft and the Optica returned to production, production ceasing in March 1990, when Brooklands Aircraft went bankrupt.

The Design of the Optica has now been bought by John Edgley once more (along with the design for the FLS Sprint 160).

Edgley hopes to put both types into production and further to that goal the Optica 300 Series s/n 021 GBOPO is being restored as a UK type demonstrator.

The P-791 is an experimental aerostatic/aerodynamic hybrid airship developed by Lockheed-Martin Corporation (Fig. 4).

The first flight of the P-791 was on 31 January 2006 at the company's flight test facility at the Palmdale Air Force Plant 42.

It has a unique tri-hull shape, with disk-shaped cushions on the bottom for landing.

A very similar design can be seen in the LongEndurance Multi-intelligence Vehicle (LEMV). 


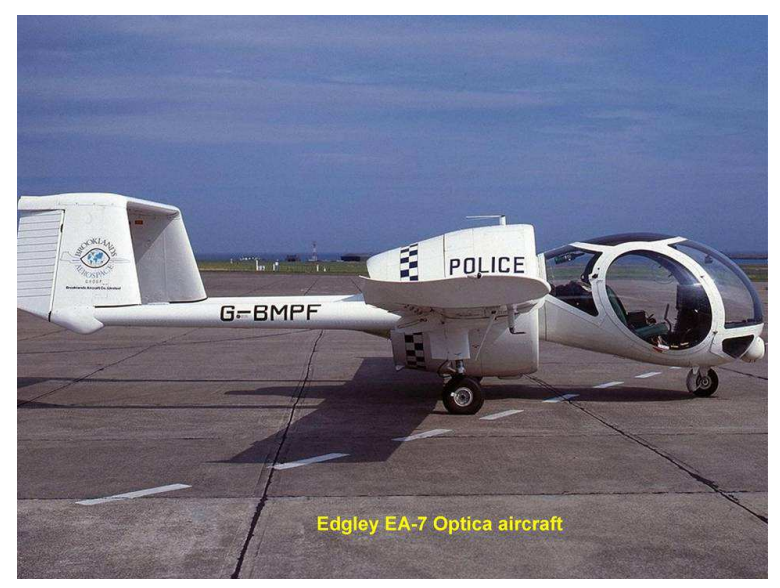

Fig. 3. Edgley EA-7 Optica aircraft. Source: Petrescu and Petrescu (2011)

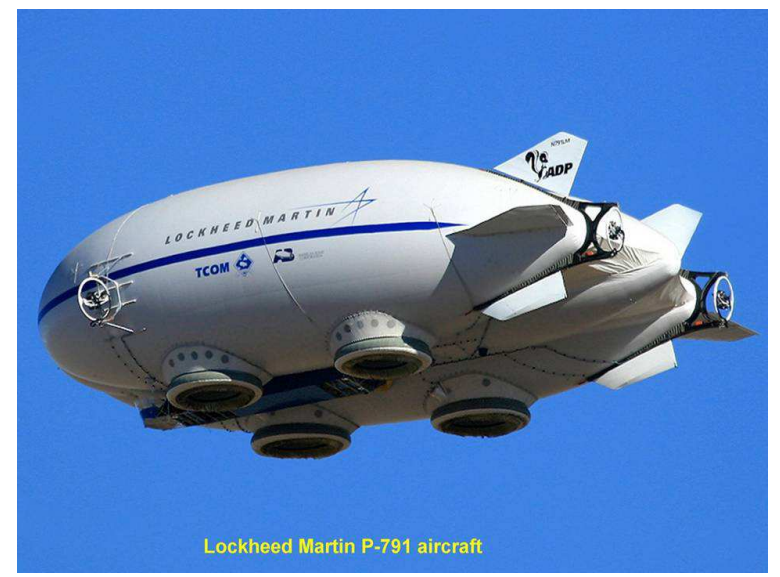

Fig. 4. Lockheed Martin P-791 aircraft. Source: Petrescu and Petrescu (2011)

The P-791 is an example of a hybrid airship. In such designs, part of the weight of the craft and its payload are supported by aerostatic (buoyant) lift and the remainder is supported by aerodynamic lift.

The combination of aerodynamic and aerostatic lift is an attempt to benefit from both the high speed of aerodynamic craft and the lifting capacity of an aerostatic craft.

Critics of the hybrid approach have labeled it as being the "worst of both worlds" in that such craft require a runway for take-off and landing, are difficult to control and protect on the ground and have relatively poor aerodynamic performance.

Proponents of hybrid designs claim that these shortcomings can be overcome through advanced technologies.

In particular, it has been proposed that buoyancy control mechanisms can minimize or eliminate the need for a runway. Recently, Worldwide Aeros Corporation has successfully tested its COSH system which will regulate its upcoming ML866's static heaviness.
No other hybrid airship design has been developed past the initial experimental stages.

Although many such designs have been proposed, very few have flown. One hybrid airship design that did take flight was the Aereon 26. The development of this aircraft was documented in the book "The Deltoid Pumpkinseed" by John McPhee.

Although Lockheed-Martin is developing a design for the DARPA project WALRUS, the company claims that the P-791 is unrelated to WALRUS. Nonetheless, the design represents an approach that may well be applicable to WALRUS.

Some believe that Lockheed-Martin has used the secret P-791 program as a way to get a head-start on Worldwide Aeros Corp, the other Phase I WALRUS competitor. The company has released no details about the design of the aircraft. However, from a distance, the P-791 appears to be essentially identical in design to the SkyCat design unsuccessfully promoted by the now defunct British company Advanced Technologies Group (ATG). SkyCat technologies are once again being developed and promoted in the US by the Hybrid Aircraft Corporation (HAC) located in New Mexico. Press reports have also confirmed that the P-791 incorporates some of the most distinctive design features of the SkyCat, specifically the use of hover/suction skirts as "landing gear."

Industry observers have noted that engineering individuals closely associated with HAC later worked on the WALRUS project and P-791 at Lockheed-Martin.

The authors of this paper are convinced that such ships will gain more ground in the next 50-200 years and will grow more and more to the detriment of classical planes because such aircraft are safer during the flight, high quality, pleasant travel, can stay in air for weeks or months effortlessly and without high energy consumption, do not depend on the bearer, wings, but keep at any desired altitude naturally because of utilized gas more lighter than air, they can take off and land vertically in any conditions easily, do not need airports and special tracks, are much easier to handle and coordinate, making trips very enjoyable, with increased comfort.

A plane of a high overall gauge is Airbus A300B4608ST Super Transporter (Fig. 5).

It can carry even and an aircraft (Fig. 6).

The BD-5 Micro (Fig. 7) is a series of small, singleseat homebuilt aircraft created in the late 1960 s by US aircraft designer Jim Bede and introduced to the market primarily in "kit" form by the now-defunct Bede Aircraft Corporation in the early 1970 s.

The BD-5 has a small, streamlined fuselage holding its semi-reclined pilot under a large canopy, with the engine installed in a compartment in the middle of the fuselage and a propeller or the jet engine in the BD-5J variant mounted immediately to the rear of the cockpit. The combination of fighter-like looks and relatively low cost led to the BD-5 selling over 5,000 kits or plans, with 
approximately 12,000 orders being taken for a proposed factory-built FAA-certified version. However, few of the kit versions were actually completed due to the company's bankruptcy in the mid-1970s and none of the factory built "D" models produced, brought on by the failure to deliver a reliable engine for the design.

In total, only a few hundred BD-5 kits were completed, although many of these are still being flown today. The BD$5 \mathrm{~J}$ version holds the record for the world's lightest jet aircraft, weighing only $358.8 \mathrm{lb}(162.7 \mathrm{~kg})$.

Development of the "Micro" dates back as early as 1967 when Jim Bede was inspired by the Schleicher ASW 15. At the time, however, Bede was working on the Bede BD-4 design. The BD-4 was a fairly conventional looking high-wing four-seater, but it offered good performance and was fairly inexpensive. Over the lifetime of the company about 600 BD-4s were sold, a success by any measure.

Serious work on the Micro started in 1970, with the construction of the prototype starting in earnest late that year. While the BD-4 was fairly conventional looking, the Micro was a radical design. It is an extremely small one-seat design that looked more like a jet fighter than a "prop plane," with the pilot sitting in a semi-reclined position under a large fighter-like plexiglass canopy only inches above the pilot's head. Behind the cockpit was a compartment housing a two-cylinder air-cooled $40 \mathrm{hp}$ engine driving a pusher propeller. Two versions were planned, the BD-5A with "short" 14' 3" (4.34 m) wings tuned for high speeds and acrobatics and the BD-5B with a $21^{\prime} 6^{\prime \prime}(6.55 \mathrm{~m})$ wings for longer range and powered glider use. Builders could optionally buy both wings, switching them in about $10 \mathrm{~min}$.

For improved performance, the aircraft featured both a V-tail and retractable landing gear in order to reduce drag. Calculated drag was so low that spoilers were added to the wing in order to improve deceleration for landing. This was apparently the first application of spoilers on a light aircraft. The low drag implied excellent performance; with the short wings, it would reach $210 \mathrm{mph}(340 \mathrm{~km} / \mathrm{h})$ in cruise, while the long-wing BD-5B would be only slightly slower and have an extended range of 1,215 miles.

In addition to being easy to fly, the BD-5 was also intended to be easy to build and own. The fuselage was constructed primarily from fiberglass panels over an aluminum frame, reducing construction time to only a few hundred h. Although the early designs required some welding in the landing gear area, it was planned that this would be removed in the kit versions, so construction would require no special tooling or skills. Even the cost of operation would be extremely low, offering fuel efficiency of almost $40 \mathrm{mpg}$. With the wings removed the aircraft could be packed into a small custom trailer, allowing it to be towed away by car for storage in a garage and from there to any suitable flat area for takeoff.
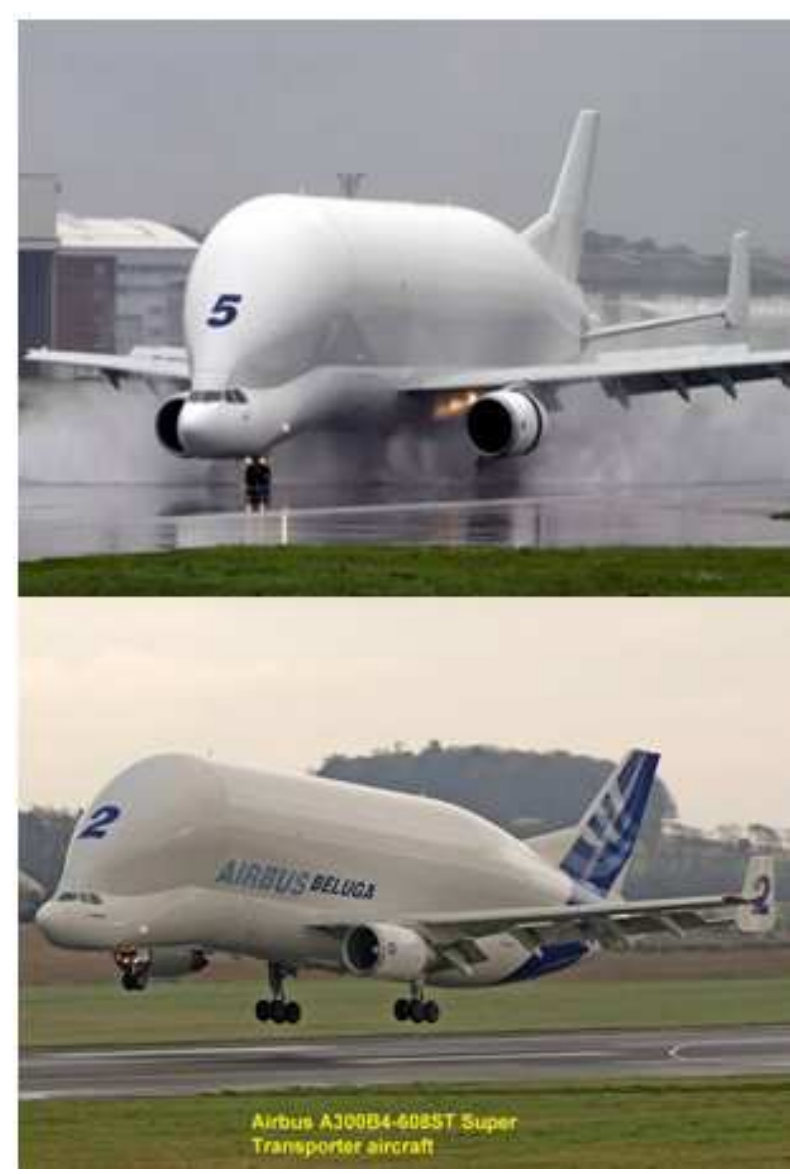

Fig. 5. Airbus A300B4-608ST Super Transporter aircraft. Source: Petrescu and Petrescu (2011)

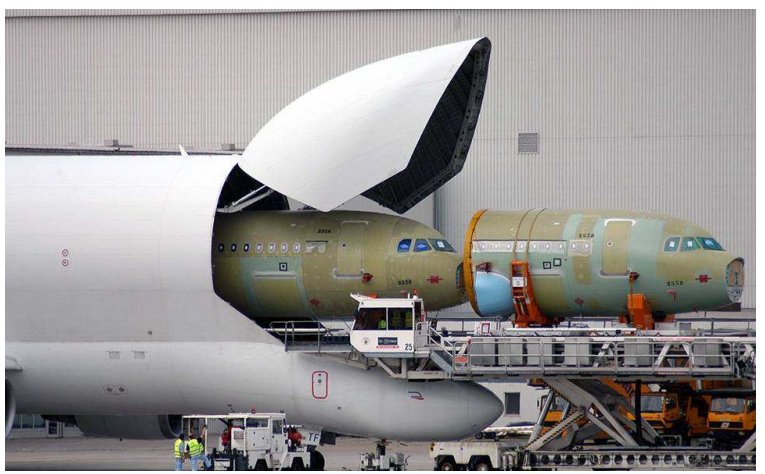

Fig. 6. Airbus A300B4-608ST Super Transporter aircraft. Source: Petrescu and Petrescu (2011)

Bede published an information booklet about the BD5 in November 1970. Several very positive magazine articles appeared at this point. The October 1971 issue of Science \& Mechanics had the BD-5 on the cover, listing the price as $\$ 1,950$ and a top speed of $215 \mathrm{MPH}$. The associated article showed the construction of the original prototype, with numerous claims about how easy it was to construct. The August 1973 issue of Popular Science 
also covered the aircraft, although it listed the price at $\$ 2,965$. A feeding frenzy followed as the "mini fighter" generated intense demand. As one author put it, "Even before the plane first left the ground, thoughts of flying the sleek, bullet-shaped aircraft with its pusher prop stimulated the imagination of nearly everyone who had heard of the program."

On February 24, 1971, the first \$200 deposit to reserve a "place in line" to receive a kit was accepted, with the target shipping date being May 24, 1972. By August 1971, 800 deposits had been taken, even though the first BD-5 prototype had yet to complete high-speed taxi tests. By the end of the year, they had over 4,300 orders, making it one of the most popular general aircraft projects in modern history.

The prototype, N500BD, flew briefly on September 12, 1971, powered by a $36 \mathrm{hp}$ Polaris Industries snowmobile engine. The stability of the aircraft with the original V-tail was marginal at best and clearly needed a redesign. With the original fiberglass fuselage this was a time-consuming process, so the decision was made to switch to an all-metal fuselage with the components incorporating compound curves produced using hydroformed aircraft-grade aluminum alloy. These could be modified with relative ease during the testing cycle. It also made economic sense as the orders rolled in, as assembly line production of stamped metal parts is expensive to set up but less expensive in the long run.

By December 1971 the tooling for the new fuselage was in development. The aircraft now featured a longer, more pointed nose, whereas the more ovoid N500BD had been patterned on the ASW 15. While this work was in progress, Bede continued to experiment with modifications to the tail, eventually abandoning the Vtail and changing to a more conventional vertical rudder and horizontal elevator layout with highly swept surfaces. Further testing on N500BD showed flow interference between the horizontal surfaces and the propeller and the elevator was raised six inches to correct it, placing it about mid-way up the rear fuselage.

The first example of the new fuselage arrived in March 1972 and was fitted with a new Kiekhaefer Aeromarine engine Bede had seen at the Oshkosh Airshow in 1971. Finished as N501BD, numerous small delays prevented it from flying until July 11, 1972. These flights demonstrated continued problems with the tail design, which was again redesigned, losing the sweep and becoming much more conventional.

The program was now far too large for Bede to handle alone. In March 1972, he hired Burt Rutan to head the flight test department, who was soon followed by Les Berven as chief test pilot. They took over development, giving Bede more time to work on business issues. This was proving difficult enough, as Kiekhaefer and Bede could not reach an agreement about deliveries, forcing him to change to a similar 440 cc $40 \mathrm{hp}$ Hirth Motoren design, but then selecting a larger $650 \mathrm{cc} 55 \mathrm{hp}$ Hirth engine instead.

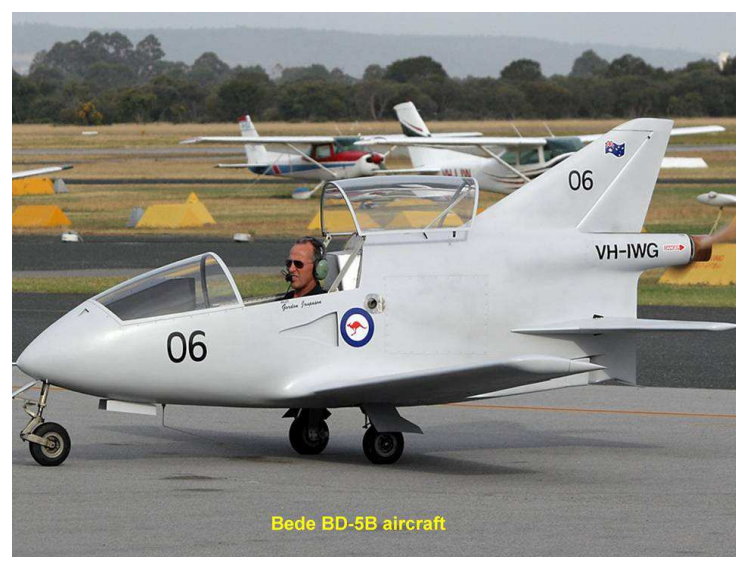

Fig. 7 Bede BD-5B aircraft. Source: Petrescu and Petrescu (2011)

Several additional problems turned up during testing. Stick forces were very low, but this was easily addressed by making the servo tabs larger. A more worrying development was that the engines all had problems with mixture due to changes in engine speed or load, which led to rough engine operation. In August Bede was demonstrating the BD-5 to the FAA in order to receive permission to fly at Oshkosh, when the engine seized. On its deadstick landing, the aircraft overran the runway, buckling the nose gear. The air-fuel mixture was identified as the cause of the crash of N501BD in September 1972 when the mixture control broke and Berven had to execute a forced landing. Since N502BD would be ready in two months, N501BD was not repaired.

However, N502BD ran into problems of its own. The earlier models used a variable speed belt drive system to transfer power from the engine to the propeller shaft, but this was removed from N502BD and it suddenly began exhibiting a serious vibration problem. Experts were called in and additional bearings corrected the problem, but it was not until March 26, 1973, that N502BD flew. From then on the test program seemed to go more smoothly.

By the time the test program neared its conclusion the aircraft had undergone major changes. One victim of the program was the shorter "A" wing, which calculations showed would only improve performance at speeds very close to Vmax (the highest available speed). Flight testing also showed the landing speed with the smaller wing was decidedly fast. Split flaps and spoilers had also disappeared. The canopy and cockpit dimensions had changed and the aircraft had new landing gear systems and a completely new tail section. More ominous was the fact that the engines had already been changed twice. What remained, however, was the basic concept of the fighter-like pusher aircraft which, if anything, had improved in looks.

By this point, it seemed the basic design was complete and Bede turned his attention to other projects. One was a jet-powered BD-5, the BD-5J, which is detailed below. Another was the Bede BD-6, a single- 
seat version of the BD-4 based on the same Hirth engine being used in the BD-5. Still, another was the "new" Bede BD-7, a two-seat side-by-side version of the BD-5 of which a prototype was built. There was even an attempt to sidestep the engine problem with the BD-5S, a glider (S for Sailplane) version with lengthened wings and no engine, which prompted Air Progress magazine to sarcastically note, "At last, a BD-5 with no engine problems". This glider version did not fly well and the project was scrapped. Bede also decided to seek FAA certification of the BD-5D as a production aircraft and sell it complete and began taking $\$ 600$ deposits for this model.

By the middle of 1973, the basic design was complete and the tooling set up for production. The engines were the only part holding up deliveries, so Bede offered to ship the kit with the engine to follow. This was a fairly attractive option; it meant the builder could "get to work" and hopefully complete the airframe by the time the engine arrived, at that point expected in September 1973. Many builders took the company up on the offer, only to receive incomplete kits and plans.

All three Hirth engines were offered; builders could keep the $40 \mathrm{hp}$ design, or "trade up" to the larger $55 \mathrm{hp}$ or $70 \mathrm{hp}$ engines. The latter, which Bede had developed with Hirth, was now considered the baseline engine for the aircraft as the original $40 \mathrm{hp}$ proved to be of insufficient power. In a late 1973 newsletter to prospective owners, Bede suggested the $70 \mathrm{hp}$ model and discouraged use of the smaller engines. Prices had risen throughout the 30 months since the deposits were first taken. Originally priced at $\$ 1,799$, the base price was raised to $\$ 2,599$ with the $55 \mathrm{hp}$ and owners were offered a "trade up" for the difference in price if they had ordered the aircraft with the original $40 \mathrm{hp}$ engine.

When 1974 came around, the engines were still not being delivered in quantity, although some started to arrive early that year. At that point, unexpectedly, Hirth went bankrupt after about 500 of the engines had shipped. Once again the design lacked a suitable engine, but this time the search for a replacement ended with a Xenoah design from Japan. Development of this engine was lengthy and in the end, it would not be certified for export until 1978, although this was not expected at the time.

In the meantime, Bede came up with another novel solution to the problems of converting pilots to the new aircraft. They took an engine-less example and bolted it to the front of a pickup truck on a trapeze, attaching the pilot's throttle control to the truck's. Pilots could test fly the aircraft without danger - if a problem developed the driver of the truck simply hit the brakes.

After more than 5,100 kits had been delivered to prospective builders, the kits stopped shipping as well. Although the company was effectively bankrupt at this point, work on the BD-5D continued for some time. The bankruptcy became official in 1979 , by which point the BD-5 project was long dead. During the bankruptcy proceedings, it was learned that the money ostensibly being used to build kits was instead being spent on a variety of projects. As a result, Bede entered a consent decree with the FTC to no longer accept deposits on aircraft for a period of 10 years.

Many owners stored, abandoned, or sold their incomplete kits, but a few hundred diehard builders finished them with a variety of engine solutions designed by third parties and former Bede Aircraft dealers. Having to hunt for an engine was only one problem. The time to build the aircraft was much longer than quoted, as much as 3,000 to $3,500 \mathrm{~h}$. Some of this was due to the need to fit their selected engine into an airframe designed for the Hirth, which was no longer available. Additionally, some of the kits were shipped with missing parts, adding to the confusion. All of this led to a rash of kits being sold for fire sale prices, although this did allow the builders that were looking to complete their kits to do so at bargain prices. While Bede claimed the aircraft could be put together by anyone in a garage, builders generally agree that doing so without proper construction techniques could result in a potentially dangerous aircraft. One way to overcome that issue is to use a set of properly laid-out jigs to align and drill the pilot holes for the airframe, wings and other components. For all of these reasons, it was some time before completed BD-5s started to appear.

Over the next few years, the aircraft garnered a terrible safety record. Although Bede had suggested using the B-wings, the earliest kits shipped only with the short "A" wings. All four examples completed with these wings crashed on their first flight, three on takeoff and one lasted long enough to crash on landing, three of the four causing fatalities. Of the first 25 completed, with both the "A" and "B" wings, 14 crashed with 9 fatalities.

Even when examples with the "B" wings were completed, the safety record did not improve greatly. Several crashes in the $-5 \mathrm{~B}$ models were found to have taken place due to engine failure on takeoff, both due to the mix of "oddball" engines as well as endemic cooling problems. The reason this is such an issue with the BD-5 is twofold - the high line of thrust means an engine failure immediately results in an unexpected (for most pilots) nose-up attitude change. Pilots who fail to fly the aircraft first and then attempt to restart the engine inevitably stall, with the associated consequences. This was aggravated by the fact the original wing had a very sharp stall with little warning and a nasty tendency to "snap roll." To make matters worse, a documented manufacturing error in some wing skins delivered to kit builders exacerbated the problem. A rather small center of gravity range also added to the problems of properly trimming the aircraft.

With the demise of the Bede Aircraft Company, the BD-5 entered a sort of limbo while builders completed their kits. The early safety problems and the challenge of adapting a suitable engine exacerbated delays. Over the next few years, however, 
solutions to most of these problems arrived in one form or another. Many other changes have also been incorporated to improve the original design. Today the BD-5 is a rewarding if demanding aircraft.

For instance, the problem of finding a suitable engine with 60 to $70 \mathrm{hp}$ yet still weighing under $100 \mathrm{lbs}$ was a serious problem in the $1970 \mathrm{~s}$, but today there are a number of "off the shelf" designs in this class. The widely available Rotax 582 is a $65 \mathrm{hp}$ engine of $80 \mathrm{lbs}$ in standard configuration, almost tailor-made for the BD-5. Other engines successfully used in BD-5s include the Subaru EA-81, Honda EB-1 and EB-2 (with and without turbocharging), Hirth 2706, AMW 225-3 and 2SI 808. The current record holder of the FAI C-1a/0 (300 kg or less takeoff weight) class speed record over a $3 \mathrm{~km}$ (1.9 mi) course at restricted altitude is a BD-5A (listed as BD-5B but used $-5 \mathrm{~A}$ wings for the record attempt) with a Rotax $618 \mathrm{UL}$ $74 \mathrm{hp} \mathrm{two-stroke,} \mathrm{two-cylinder} \mathrm{water-cooled} \mathrm{engine.}$

Problems with the abrupt stall were mostly addressed by Harry Riblett, an airfoil designer who documented a procedure to apply a slight reprofile of the wing root airfoil which softened the stall response of the aircraft without any significant performance degradation. The reprofile presents other unique problems associated with the way it is applied to the wing upper surface, essentially gluing foam to the aluminum skin and covering with fiberglass. Similarly, the small center-ofgravity range has since been addressed with 5.5- to 13inch stretch kits for the fuselage.

Several companies were formed to help builders complete their kits and many of the aftermarket modifications were worked into these services. Today, BD Micro Technologies of Siletz, Oregon continues to offer kit building support, including new-build kits featuring (optionally) all of these modifications and even the BD-5T, a turboprop version of the BD-5 using a modified Solar T62 turbine powering a mechanicallycontrolled variable-pitch propeller. Alturair, Inc. of San Diego, California also offers extensive parts and construction assistance services.

An unusual adaptation of the BD-5, the Acapella 100, appeared in the early 1980s. Designer Carl D. Barlow of Option Air Reno mated a BD-5 fuselage with a distinctive twin-boom empennage and fitted it with a $100 \mathrm{hp}$ Continental O-200 engine. Later, a $200 \mathrm{hp} \mathrm{Lycoming} \mathrm{IO-}$ 360 was fitted and the wings shortened from 26.5 feet to 19.5 feet, becoming the Acapella 200-S model. The prototype of this aircraft was first flown on June 6, 1980, with pilot Bill Skiliar at the controls. Nonetheless, it flew poorly and was difficult to control. Only the one prototype was built and it was donated to the Experimental Aircraft Association's Airventure Museum in Oshkosh, Wisconsin, USA, where it is occasionally placed on display.

Bede Aircraft Company has since re-formed and has been working on several new designs. Bede has hinted at a two-seat tandem version of the aircraft called the
"Super BD-5" using a certified aircraft engine and a number of modifications and improvements, but to date, nothing other than a preliminary design drawing has been made available.

While the new Hirth engine was being tested, Bede decided to create an unconventional variant of the BD-5 with a small jet engine. The result was the sleek BD-5J, a $300 \mathrm{mph}(480 \mathrm{~km} / \mathrm{h})$ aircraft. The design used the Sermel TRS-18-046 turbojet (now Microturbo, a division of Turbomeca), which produced $225 \mathrm{lbs}$ of thrust and was used on a Caproni certified motor glider design. The original engines were produced under license by Ames Industrial in the USA. The wing was modified to an "intermediate" size between the original $A$ and $B$ wings, with a $17 \mathrm{ft}$ span.

Bob Bishop had purchased 20 BD-5J kits as soon as they had appeared and many of the flying examples started life in this batch of twenty. Versions from the original batch became a popular airshow fixture. Throughout the 1980s and until 1991, Coors flew two of them as the "Silver Bullets." Budweiser also had a BD$5 \mathrm{~J}$ called the "Bud Light Jet", but that contract has long expired and the aircraft was lost as a result of an engine compartment fire from which Bob Bishop successfully bailed out. The aircraft also appeared in the opening sequence of the James Bond film, Octopussy.

Many of these aircraft have since been involved in crashes. The loss of the Bud Light Jet was caused by an incorrectly specified fuel flow sending unit which burst in mid-flight and caused fuel to be sprayed directly into the engine compartment. The fuel ignited when it came in contact with the hot components of the turbojet engine, forcing the pilot to trade speed for altitude, climb and bail out. The aircraft then went into a flat spin and pancaked into the ground, but was sufficiently intact to allow the cause of the fire to be determined relatively quickly.

On June 16, 2006, while practicing for an air show at Carp Airport in Ottawa, Canada, Scott Manning fatally crashed in his "Stinger Jet," the last BD-5J that remained on the airshow circuit. The Transportation Safety Board of Canada investigated the accident and issued a report assigning the probable cause to the incorrect installation of the right wing, which caused the flap on that wing to suddenly retract in flight and create a "split flap" condition. The aircraft rolled to the right and Manning was unable to recover in time.

Recently, the BD-5J operates in the national security arena. The aircraft is certified by the United States Department of Defense as a cruise missile surrogate, with Bishop's Aerial Productions offering a version known as the Smart-1 (Small Manned Aerial Radar Target, Model 1). The radar return and general performance characteristics make it a useful aid in training. On June 27, 2006, while flying one of these aircraft, pilot Chuck Lischer, a highly experienced professional air show pilot, impacted trees on final 
approach to the Ocean City Municipal Airport in Ocean City, Maryland in a fatal accident.

The BD-5J has also held the Guinness record for the World's Smallest Jet for more than 25 years. Bob Bishop originally garnered the record with one of his jets and in November 2004 the record changed hands to Juan Jiménez, who purchased the aircraft from the original builder whose BD-5J weighed in at $358.8 \mathrm{lb}(162.7 \mathrm{~kg})$ empty weight, $80 \mathrm{lb}(36 \mathrm{~kg})$ lighter than Bishop's jet and the lightest documented weight for a BD-5. The jet has not yet flown due to significant mechanical issues, turbine starting and safety concerns.

Another monster is Boeing 707-385C Phalcon aircraft (Fig. 8).

The McDonnell Douglas YC-15 and its successor, the Boeing C-17 Globemaster III, also employ the effect. The NOTAR helicopter replaces the conventional propeller tail rotor with a Coanda effect tail (Fig. 9).

According to NASA, "ERAST is a multiyear effort to develop the aeronautical and sensor technologies for a new family of remotely piloted aircraft intended for upper atmospheric science missions. Designed to cruise at slow speeds for long durations at altitudes of 60,000 to $100,000 \mathrm{ft}$, such aircraft could be used to collect, identify and monitor environmental data to assess global climate change and assist in weather monitoring and forecasting. They also could serve as airborne telecommunications platforms, performing functions similar to communications satellites at a fraction of the cost of lofting a satellite into space." (Fig. 10).

"The ERAST program is sponsored by the Office of Aeronautics and Space Transportation Technology at NASA Headquarters and is managed by NASA Dryden Flight Research Center. The NASA Ames Research Center, Moffett Field, California, heads the sensor technology development. The NASA Lewis Research Center, Cleveland, Ohio and NASA Langley Research Center, Hampton, Virginia, are contributing expertise in the areas of propulsion, structures and systems analysis. Several small high-technology aeronautical development firms, including ALTUS developer General Atomics Aeronautical Systems, Inc., are teamed with NASA in the ERAST Alliance to work towards common goals of the program." Industry partners in the ERAST Alliance included Aurora Flight Systems, AeroVironment, General Atomics, Scaled Composites, Thermo-Mechanical Systems, Hyperspectral Sciences and Longitude 122 West.

The types of science mission which ERAST prepares for can include remote sensing for Earth sciences studies, hyperspectral imaging for agriculture monitoring, tracking of severe storms and serving as telecommunications relay platforms.

A parallel effort headed by Ames developed lightweight, microminiaturized sensors that can be carried by these aircraft for environmental research and Earth monitoring.

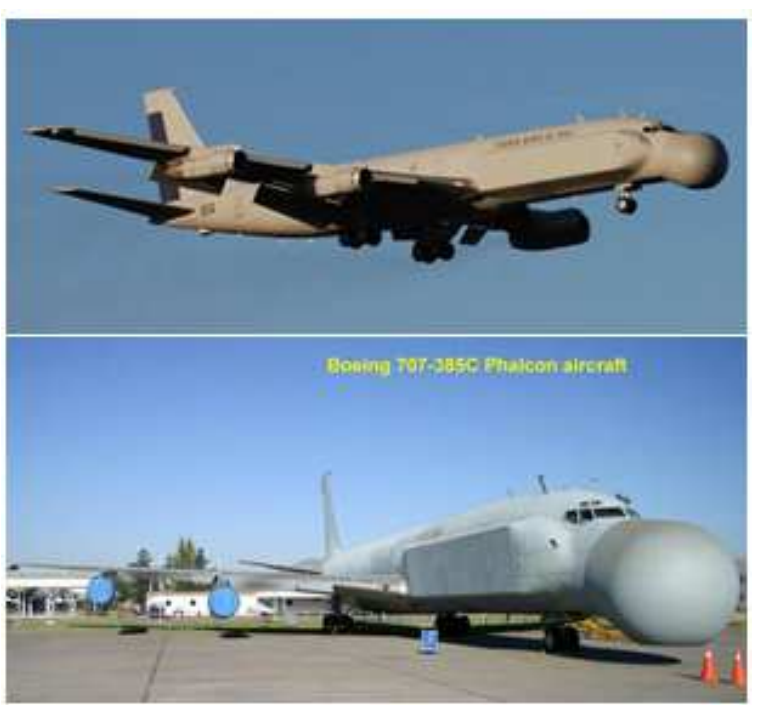

Fig. 8. Boeing 707-385C Falcon aircraft. Source: Petrescu and Petrescu (2011)

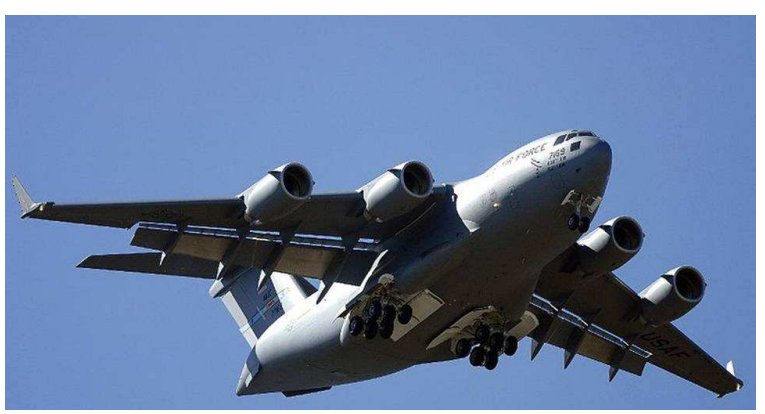

Fig. 9. The C-17 Globemaster III uses the Coanda effect for a comfortable ride at low flying speeds. Source: Petrescu and Petrescu (2011)

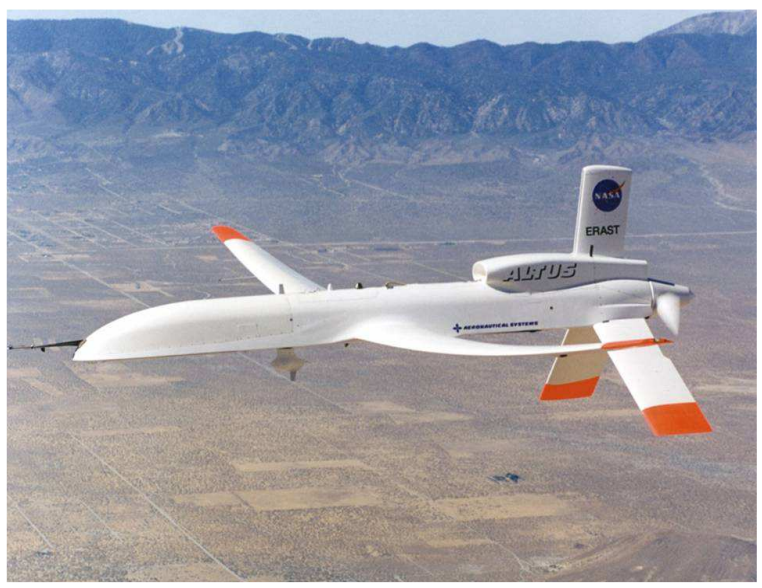

Fig. 10. ERAST is a multiyear effort to develop the aeronautical and sensor technologies for a new family of remotely piloted aircraft intended for upper atmospheric science missions. Source: Petrescu and Petrescu (2011) 
Additional technologies considered by the ERAST Alliance include lightweight materials, avionics, aerodynamics and other forms of propulsion suitable for extreme altitudes and duration.

Although ERAST Alliance members were responsible for aircraft development and operation, NASA had primary responsibility for overall program leadership, major funding, individual project management, development and coordination of payloads. NASA also worked on long-term issues with the Federal Aviation Administration and developed technology to make the operation of these remotely operated aircraft in national airspace practical.

The Lockheed SR-71 "Blackbird" (Fig. 11) was an advanced, long-range, Mach 3+ strategic reconnaissance aircraft. It was developed as a black project from the Lockheed A-12 reconnaissance aircraft in the 1960s by the Lockheed Skunk Works. Clarence "Kelly" Johnson was responsible for many of the design's innovative concepts. During reconnaissance missions, the SR-71 operated at high speeds and altitudes to allow it to outrace threats. If a surface-to-air missile launch was detected, the standard evasive action was simply to accelerate and outrun the missile.

The SR-71 served with the U.S. Air Force from 1964 to 1998. Although twelve of the 32 aircraft built were destroyed in accidents, none were lost to enemy action. The SR-71 was unofficially named the Blackbird and called the Habu by its crews, referring to an Okinawan species of pit viper. Since 1976, it has held the world record for the fastest air-breathing manned aircraft, a record previously held by the YF-12.

One experimental two-seat A-10 Night Adverse Weather (N/AW) version was built by converting an A-10A.

The N/AW was developed by Fairchild from the first Demonstration Testing and Evaluation (DT\&E) A-10 (Fig. 12) for consideration by the USAF.

It included a second seat for a weapons system officer responsible for electronic countermeasures (ECM), navigation and target acquisition.

The variant was canceled and the only two-seat A-10 built now resides at Edwards Air Force Base's Flight Test Center Museum.

The N/AW version did not interest the USAF or export customers. The two-seat trainer version was ordered by the Air Force in 1981, but funding was canceled by U.S. Congress and the jet was not produced. The Embraer EMB 314 Super Tucano, also named ALX or A-29 (Fig. 13) is a turboprop aircraft designed for light attack, Counter Insurgency (COIN) and pilot training missions, incorporating modern avionics and weapons systems. It is currently in service with the air forces of Brazil, Dominican Republic and Colombia and has been ordered by the forces of Chile and Ecuador. Embraer has plans to sell it to other countries in Asia and the Middle East. Besides pilot training, it is heavily employed in monitoring operations within the Amazon basin.

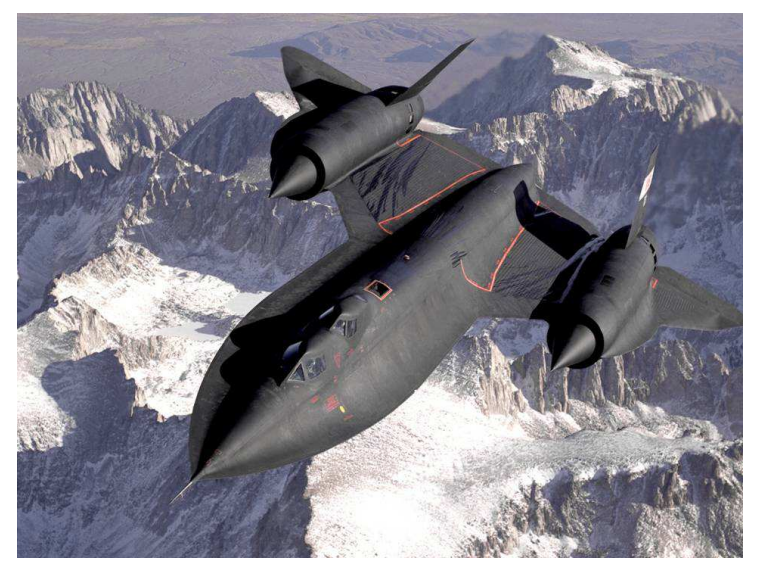

Fig. 11. Lockheed SR-71 blackbird. Source: Petrescu and Petrescu (2011)

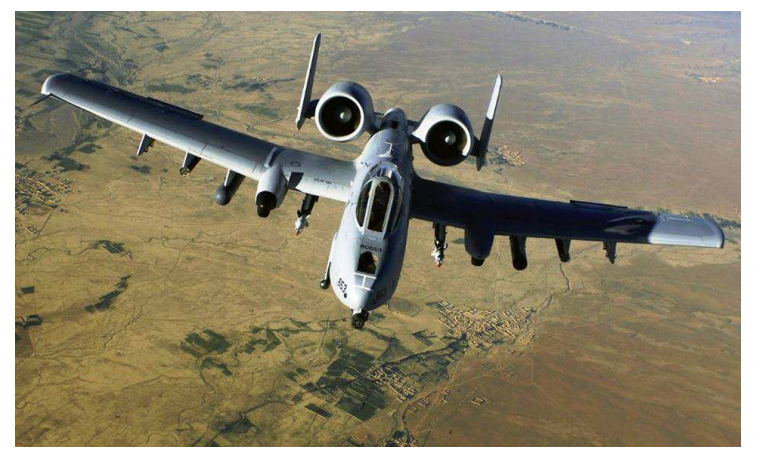

Fig. 12. A-10 Thunderbolt. Source: Petrescu and Petrescu (2011)

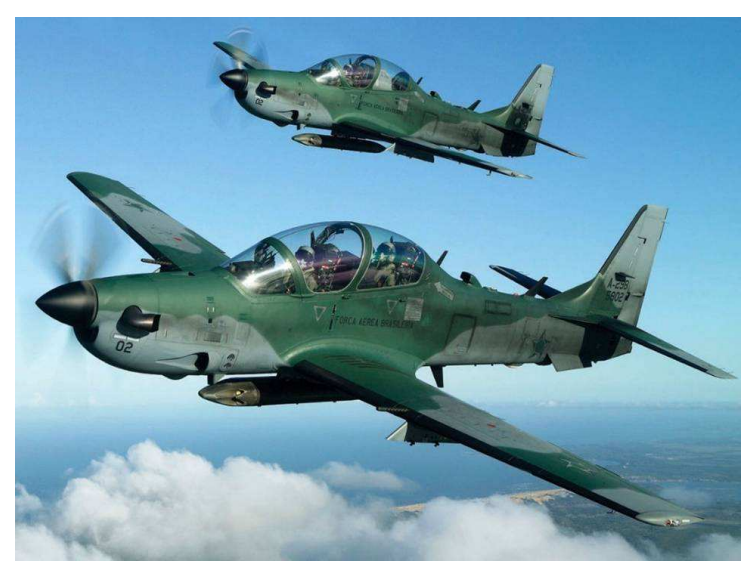

Fig. 13. A-29 super tucano. Source: Petrescu and Petrescu (2011)

More recently, Kuwaiti Air Force Skyhawks fought in 1991 during Operation Desert Storm. When Iraq invaded Kuwait, the available Skyhawks flew attack missions against the advancing Iraqi forces from deserted roads after their bases were overrun. A total of 24 of the 29 A-4KUs that remained in service with Kuwait (from 36 delivered in the 1970s) escaped to 
Saudi Arabia. The escaped Skyhawks (along with escaped Mirage F1s) operated as the Free Kuwait Air Force, flying 1,361 sorties during the liberation of Kuwait. Twenty-three A-4s survived the conflict and the Iraqi invasion, with only one being destroyed in combat. The remaining Kuwaiti Skyhawks were later sold to Brazil, where they currently serve aboard the aircraft carrier NAe São Paulo.

Figure 14 it can see a modern aircraft A-4 Skyhawk. These devices (A-4) have taken the brunt of the fighting over for decades.

In the early 1960s, European air forces began to consider their requirements for the coming decades. One of the results was the emergence of a new generation of jet trainers to replace such aircraft as the Lockheed T-33 and Fouga Magister. The two main rivals in this exercise turned out to be the BAe Hawk and the Franco-German Dassault-Dornier Alpha Jet (Fig. 15).

At the outset, the Alpha Jet had a lead, but the BAe Hawk would prove to be the winner in the race. However, the Alpha Jet has been built in good numbers and served with a number of air forces for several decades.

The Avro Vulcan (Fig. 16), sometimes referred to as the Hawker Siddeley Vulcan is a delta wing subsonic jet strategic bomber that was operated by the Royal Air Force (RAF) from 1953 until 1984. It was developed by Avro in response to a specification released by the Air Ministry. At the time, both jet engines and delta wings were considered cutting-edge and relatively unexplored; thus, the small-scale Avro 707 was produced to test the principles of the design. In flight, the Vulcan was an agile aircraft for its size.

The Vulcan B.1 was first delivered to the RAF in 1956. In service, the Vulcan was armed with nuclear weapons and was a part of the RAF's V bomber force, the United Kingdom's airborne deterrent against aggression from other powers such as the Soviet Union during the Cold War. In addition to an extensive electronic countermeasures suite, the Vulcan had a small radar crosssection, aiding its deterrent role by evading detection and therefore increasing the likelihood of penetrating Soviet airspace and deploying its weapons load successfully.

The second batch of aircraft, the B.2, was produced with new features, including a larger wing and greater fuel capacity, along with more advanced electronics and radar systems.

The B.2s were adapted into several other variants, the B.2A carrying the Blue Steel missile, the B.2 (MRR) for Marine Radar Reconnaissance use and the K.2 tanker for aerial refueling. The Vulcan was also used in the secondary role of a conventional bombing near the end of its service life in the 1982 Falklands War against Argentina during Operation Black Buck. One example, XH558, was recently restored for use in display flights and commemoration of the employment of the aircraft in the Falklands conflict.

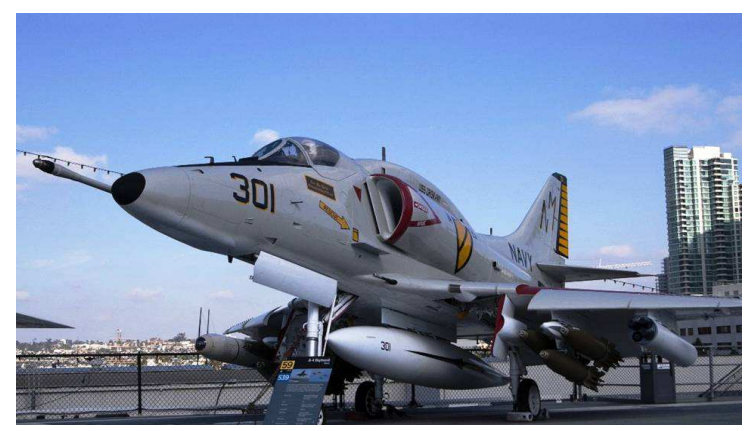

Fig. 14. This is a modern aircraft A-4, Skyhawk. Source: Petrescu and Petrescu (2011)

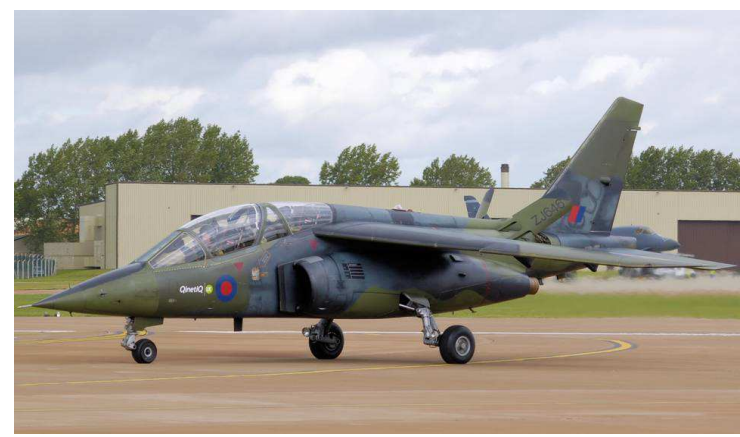

Fig. 15. Alpha Jet. Source: Petrescu and Petrescu (2011)

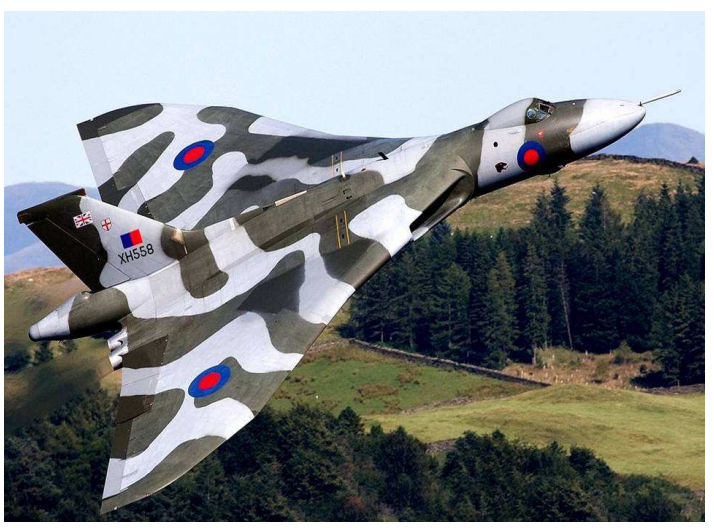

Fig. 16. Avro Vulcan. Source: Petrescu and Petrescu (2011)

The Rockwell (now part of Boeing) B-1 Lancer (Fig. 17) is a four-engine, variable-sweep wing strategic bomber used by the United States Air Force (USAF).

First envisioned in the 1960s as a supersonic bomber with sufficient range and payload to replace the Boeing B52 Stratofortress, it developed primarily into a low-level penetrator with long range and supersonic speed capability.

Designed by Rockwell International, the bomber's development was delayed multiple times over its history, as the theory of strategic balance changed from flexible response to mutually assured destruction and back again. The initial B-1A version was developed in the early 1970 s, but its production was canceled and only four 
prototypes were built. In 1980, the B-1 resurfaced as the $\mathrm{B}-1 \mathrm{~B}$ version with the focus on low-level penetration bombing. The B-1B entered service with the USAF in 1986. It began service with the USAF Strategic Air Command as a nuclear bomber.

In the 1990s, the B-1B was converted to conventional bombing use. It was first used in combat during Operation Desert Fox in 1998 and during the NATO action in Kosovo the following year. The B-1B continues to support U.S. and NATO military forces in Afghanistan and Iraq. The Lancer is the supersonic component of the USAF's long-range bomber force, along with the subsonic B-52 and Northrop Grumman B-2 Spirit. The bomber is commonly called the "Bone" (originally from "B-One"). With the retirement of the General Dynamics/Grumman EF-111A Raven in 1998 and the Grumman F-14 Tomcat in 2006, the B-1B is the U.S. military's only active variable-sweep wing aircraft. The B-1B is expected to continue to serve into the 2020s when it is to supplement by the Next Generation Bomber.

The Northrop Grumman B-2 Spirit (Fig. 18), (also known as the Stealth Bomber) is an American heavy bomber with low observable stealth technology designed to penetrate dense anti-aircraft defenses and deploy both conventional and nuclear weapons. Because of its considerable capital and operational costs, the project was controversial in the U.S. Congress and among the Joint Chiefs of Staff. During the late 1980s and early 1990s, the Congress slashed initial plans to purchase 132 bombers to 21 .

Manufactured by Northrop Grumman, the cost of each aircraft averaged US\$737 million in 1997 dollars (\$1.01 billion today). Total procurement costs averaged US\$929 million per aircraft (\$1.27 billion today), which includes spare parts, equipment, retrofitting and software support. The total program cost, which includes development, engineering and testing, averaged US\$2.1 billion per aircraft (in 1997 dollars, $\$ 2.87$ billion today).

Twenty B-2s are operated by the United States Air Force. Though originally designed in the 1980s for Cold War operations scenarios, B-2s were first used in combat to drop bombs on Serbia during the Kosovo War in 1999 and saw continued use during the wars in Iraq and Afghanistan. One aircraft was lost in 2008 when it crashed just after takeoff; the crew ejected safely. B-2s were also used during the 2011 Libyan uprising.

The bomber has a crew of two and can drop up to 80 $500 \mathrm{lb}(230 \mathrm{~kg})$-class JDAM GPS-guided bombs, or 16 $2,400 \mathrm{lb}(1,100 \mathrm{~kg}) \mathrm{B} 83$ nuclear bombs in a single pass through extremely dense anti-aircraft defenses.

The B-2 is the only aircraft that can carry large air to surface standoff weapons in a stealth configuration. The program has been the subject of espionage and counterespionage activity and the B-2 has provided prominent public spectacles at air shows since the 1990s.

The Lockheed F-117 Nighthawk (Fig. 19) is a singleseat, twin-engine stealth ground-attack aircraft formerly operated by the United States Air Force (USAF).

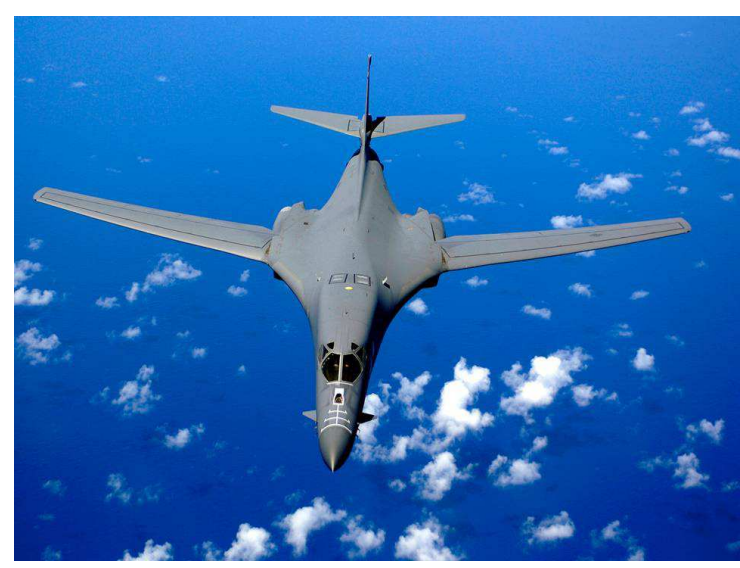

Fig. 17. B-1 Lancer. Source: Petrescu and Petrescu (2011)

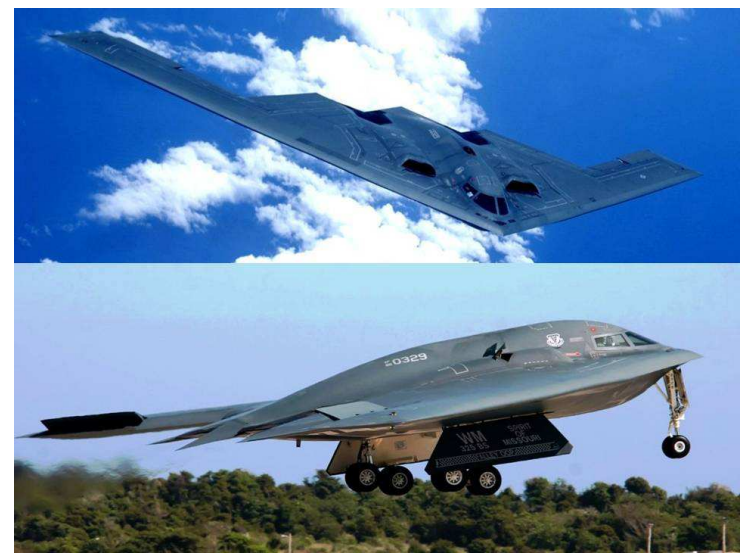

Fig. 18. B-2 Spirit (the Stealth Bomber). Source: Petrescu and Petrescu (2011)

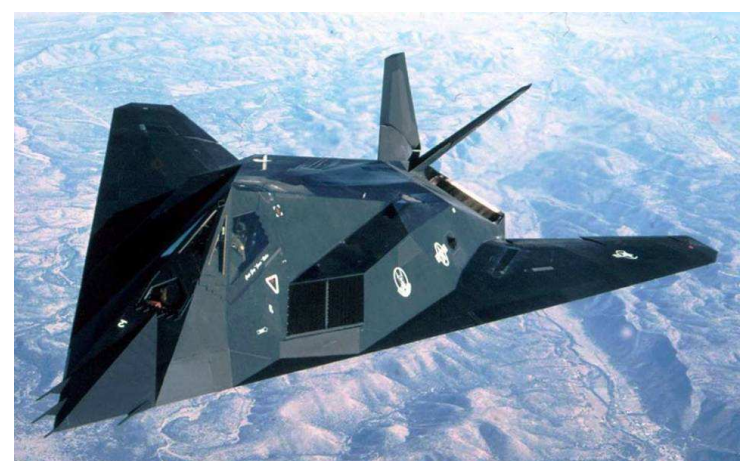

Fig. 19. The Lockheed F-117 Nighthawk. Source: Petrescu and Petrescu (2011)

The F-117A's first flight was in 1981 and it achieved initial operating capability status in October 1983. The F-117A was "acknowledged" and revealed to the world in November 1988.

A product of Lockheed Skunk Works and a development of the Have Blue technology demonstrator, it became the first operational aircraft initially designed 
around stealth technology. The F-117A was widely publicized during the Persian Gulf War of 1991. It was commonly called the "Stealth Fighter" although it was a ground-attack aircraft, making its F-designation misleading.

The Lockheed Martin/Boeing F-22 Raptor (Fig. 20) is a single-seat, twin-engine fifth-generation supermaneuverable fighter aircraft that uses stealth technology. It was designed primarily as an air superiority fighter but has additional capabilities that include ground attack, electronic warfare and signals intelligence roles. Lockheed Martin Aeronautics is the prime contractor and is responsible for the majority of the airframe, weapon systems and final assembly of the F-22. Program partner Boeing Defense, Space and Security provides the wings, aft fuselage, avionics integration and all of the pilot and maintenance training systems.

The Lockheed C-5 Galaxy (Fig. 21) is a large military transport aircraft built by Lockheed. It was designed to provide strategic heavy airlift over intercontinental distances and to carry outsize and oversize cargo. The C-5 Galaxy has been operated by the United States Air Force (USAF) since 1969 and is among the largest military aircraft in the world. The C$5 \mathrm{M}$ Super Galaxy is an upgraded version with new engines and modernized avionics designed to extend its service life beyond 2040 .

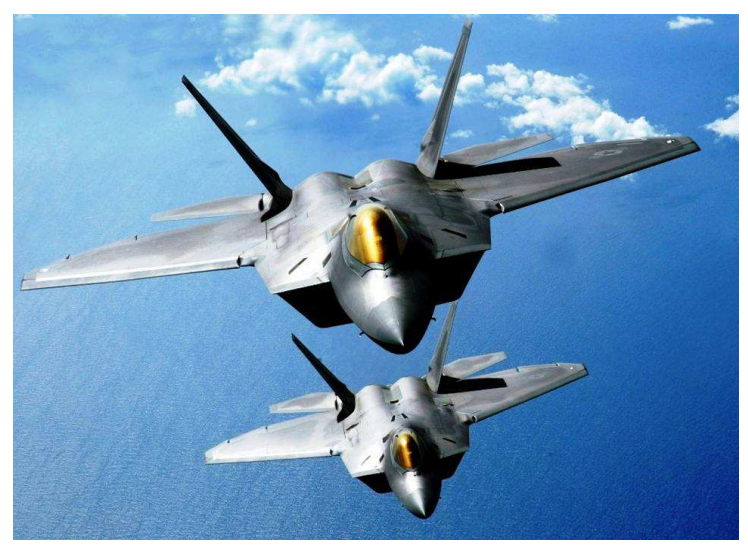

Fig. 20. The Lockheed Martin/Boeing F-22 Raptor. Source: Petrescu and Petrescu (2011)



Fig. 21. The Lockheed C-5 Galaxy. Source: Petrescu and Petrescu (2011)

\section{Results}

In 1961, several aircraft companies began studying heavy jet transport designs that would replace the Douglas C-133 Cargo master transport and complement Lockheed C-141 Star lifters. In addition to higher overall performance, the United States Army wanted a transport with a larger cargo bay than the C-141, whose interior was too small to carry a variety of their outsized equipment. These studies led to the "CX-4" design concept, but in 1962 the proposed six-engine design was rejected because it was not viewed as a significant advance over the C-141.

By late 1963, the next conceptual design was named CX-X. It was equipped with four engines, instead of six engines in the earlier CX-4 concept. The CX-X had a gross weight of 550,000 pounds $(249,000 \mathrm{~kg})$, a maximum payload of $180,000 \mathrm{lb}(81,600 \mathrm{~kg})$ and a speed of Mach $0.75(500 \mathrm{mph} / 805 \mathrm{~km} / \mathrm{h})$. The cargo compartment was $17.2 \mathrm{ft}(5.24 \mathrm{~m})$ wide by 13.5 feet $(4.11 \mathrm{~m})$ high and $100 \mathrm{ft}(30.5 \mathrm{~m})$ long with front and rear access doors. To provide required power and range with only four engines required a new engine with dramatically improved fuel efficiency.

The criteria were finalized and an official Request for Proposal was sent out in April 1964 for the "Heavy Logistics System" (CX-HLS) (previously CX-X). In May 1964, proposals for aircraft were received from Boeing, Douglas, General Dynamics, Lockheed and Martin Marietta. Proposals for engines were received from General Electric, Curtiss-Wright and Pratt \& Whitney. After a down select, Boeing, Douglas and Lockheed were given one-year study contracts for the airframe, along with General Electric and Pratt and Whitney for the engines.

All three of the designs shared a number of features. In particular, all three placed the cockpit well above the cargo area to allow for cargo loading through a nose door. The Boeing and Douglas designs used a pod on the top of the fuselage containing the cockpit, while the Lockheed design extended the cockpit profile down the length of the fuselage, giving it an egg-shaped cross section. All of the designs featured swept wings and front and rear cargo doors allowing simultaneous loading and unloading. Lockheed's design featured a T-tail, while the designs by Boeing and Douglas had conventional tails.

The Air Force considered Boeing's design better than the Lockheed design, although Lockheed's proposal was the lowest total cost bid. Lockheed was selected the winner in September 1965, then awarded a contract in December 1965. General Electric's engine design was selected in August 1965 for the new transport; the Pratt $\&$ Whitney engine design was developed and later used on the Boeing 747. 
The first C-5A Galaxy (number 66-8303) was rolled out of the manufacturing plant in Marietta, Georgia on 2 March 1968. On 20 June 1968, Lockheed-Georgia Co. began flight testing its new Galaxy C-5A heavy transport with the aircraft's first flight taking to the air under the callsign "eight-three-oh-three heavy" (8303H). Cost overruns and technical problems of the C-5A were the subjects of a congressional investigation in 1968 and 1969. The Lockheed C-5 program holds the dubious distinction of being the first program to produce a one billion dollar overrun.

\section{Discussion}

Upon completion of testing the first C-5A was transferred to the Transitional Training Unit at Altus Air Force Base, OK, in December 1969. Lockheed then delivered the first operational Galaxy to the 437th Airlift Wing, Charleston Air Force Base, SC, in June 1970. Due to the higher than expected development costs, there were calls within the military as early as in June 1970 for the government to split the losses that Lockheed were experiencing. Production was nearly brought to a halt in 1971 due to Lockheed going through financial difficulties, brought on in part due to the C-5 Galaxy but also by the civilian jet liner, the Lockheed L-1011. The U.S. government loaned Lockheed money so they could keep running.

In 1969 Henry Durham raised concerns about the C-5 production process with his employer, Lockheed. He was transferred and subjected to abuse until he resigned from the company. The GAO substantiated some of his charges against Lockheed and the American Ethical Union honored him with the Elliott-Black Award.

In the early 1970s, NASA considered the C-5 for the Shuttle Carrier Aircraft role, to transport the Space Shuttle to Kennedy Space Center. However, they rejected it in favor of the Boeing 747, in part due to the 747's low-wing design. In contrast, the Soviet Union chose to transport its shuttles using the high-winged An225, which derives from the An-124, which is similar in design and function to the C-5.

During static and fatigue testing cracks were noticed in the wings of several aircraft and as a consequence, the C-5A fleet was restricted to $80 \%$ of maximum design loads. To reduce wing loading, load alleviation systems were added to the aircraft. By 1980, payloads were restricted to as low as $50,000 \mathrm{lb}(23,000 \mathrm{~kg})$ for general cargo during peacetime operations. To restore full payload capability and service life, a $\$ 1.5$ billion program to re-wing the 76 completed C-5As began in 1976. After design and testing of the new wing design, the C-5As received their new wings from 1980 to 1987 . During 1976, numerous cracks were also found in the fuselage along the upper fuselage on the centerline, aft of the refueling port, extending back to the wing. The cracks required a redesign to the hydraulic system for the visor, the front cargo entry point.
In 1974, Iran, then a monarchy which maintained good relations with the United States, offered \$160 million to restart the production of the $\mathrm{C}-5$ to enable them to make their own procurements of the Galaxy; in a similar climate as to their acquisition of F-14 Tomcat fighters. However, no C-5 aircraft were ever ordered by Iran, as the prospect was firmly halted by the Iranian Revolution in 1979.

As part of President Ronald Reagan's military planning, a new version of the C-5, the C-5B, was approved by Congress for purchase in July 1982. The first C-5B was delivered to Altus Air Force Base in January 1986. In April 1989, the last of 50 C-5B aircraft was added to the $77 \mathrm{C}-5 \mathrm{As}$ in the Air Force's airlift force structure. The C-5B includes all C-5A improvements and numerous additional system modifications to improve reliability and maintainability.

In 1998, the Avionics Modernization Program (AMP) began upgrading the C-5's avionics to include a glass cockpit, navigation equipment and a new autopilot system. Another part of the C-5 modernization effort is the Reliability Enhancement and Re-Engining Program (RERP). The program will mainly replace the engines with newer, more powerful ones. Three C-5s are to undergo RERP as a test with full production planned to begin in May 2008.

The C-5 is a large high-wing cargo aircraft. It has a distinctive high T-tail, 25-degree wing sweep and four TF39 turbofan engines mounted on pylons beneath the wings. The $\mathrm{C}-5$ is similar in layout to its smaller predecessor, the C-141 Star lifter. The C-5 has 12 internal wing tanks and is equipped for aerial refueling. It has both nose and aft doors for "drive-through" loading and unloading of cargo.

The C-5 features a cargo compartment $121 \mathrm{ft}(37 \mathrm{~m})$ long, $13.5 \mathrm{ft}(4.1 \mathrm{~m})$ high and $19 \mathrm{ft}(5.8 \mathrm{~m})$ wide, or just over $31,000 \mathrm{cu} \mathrm{ft}(880 \mathrm{~m} 3)$. The compartment can accommodate up to $36463 \mathrm{~L}$ master pallets or a mix of palletized cargo and vehicles. The cargo hold of the C-5 is actually a foot longer than the length of the first powered flight by the Wright Brothers' Flyer at Kitty Hawk. The nose and aft doors open the full width and height of the cargo compartment to permit faster and easier loading. Ramps are full width at each end for loading double rows of vehicles.

It has an upper deck seating area for 73 passengers. The passengers face the rear of the aircraft, rather than forward. Its takeoff and landing distances, at maximum gross weight, are 8,300 ft $(2,500 \mathrm{~m})$ and 4,900 ft (1,500 $\mathrm{m})$ respectively. It's its high flotation main landing gear has 28 wheels to share the weight. The rear main landing gear is steerable for a smaller turning radius and it rotates 90 degrees horizontally before it is retracted after takeoff. The "kneeling" landing gear system permits lowering of the parked aircraft so the cargo floor is at a truck-bed height to facilitate vehicle loading and unloading. 
The C-5 has a Malfunction Detection Analysis and Recording (MADAR) system, which records and analyzes information and detects malfunctions in more than 800 test points. The $\mathrm{C}-5$ requires an average of $16 \mathrm{~h}$ of maintenance for each flight $h$ based on 1996 data. The Galaxy has a Low-Pressure Pneumatic System (LPPS) that utilizes a turbo compressor driven by bleed air to provide 150 psi pressure for inflating aircraft's tires on the ground. The LPPS is no longer used on C-5s.

The Galaxy is capable of carrying nearly every type of the Army's combat equipment, including bulky items such as the 74 short tons (67 t) Armored Vehicle Launched Bridge (AVLB), from the United States to any location on the globe.

One of the unique features was the crosswind landing system that allows the landing gear to be offset up to 20 degrees either side of the centerline. When the Main Landing Gear was down (MLG) all the other 28 wheels would be slaved to the MLG and driven by hydraulic actuators to the same offset.

The first C-5A was delivered to the USAF on 17 December 1969. Wings were built up in the early 1970s at Altus AFB, Oklahoma, Charleston AFB, Dover AFB, Delaware and Travis AFB, California. 9 July 1970 marked the C-5's first mission in Southeast Asia during the Vietnam War. Through the rest of the war, C-5s were used to transport equipment and troops, including Army tanks and various smaller aircraft. C-5s have also been used to deliver support and reinforce various U.S. allies over the years, critically delivered weapons and supplies to Israel as part of Operation Nickel Grass in 1973, in which the aircraft performed to such a high degree that the Pentagon considered further purchases. The C-5 was also made available to support British-led peacekeeping efforts in Zimbabwe in 1979.

The C-5 is the largest aircraft to ever operate in the Antarctic. Williams Field near McMurdo Station is capable of handling C-5 aircraft and the first C-5 landed there in 1989. The C-5 Galaxy was a core part of the extensive airlift operations supplying troops involved in the First Gulf War and in delivering relief aid to Rwanda in 1994.

The wings on the C-5As were replaced during the 1980 s to restore full design capability. The U.S. Air Force took delivery of the first C-5B on 28 December 1985 and the final one in April 1989. The reliability of the C-5 fleet has been a continued issue throughout its lifetime, however, the C-5M upgrade program seeks in part to address this issue.

In response to Air Force motions towards the retirement of the C-5 Galaxy, Congress implemented legislation that placed set limits upon retirement plans for C-5A models in 2003. By 2005, 14 C-5As were retired. One was sent to the Warner Robins Air Logistics Center (WR-ALC) for tear down and inspection to evaluate structural integrity and estimate the remaining life for the fleet. Thirteen C-5As were sent to the Air Force's Aerospace Maintenance and Regeneration Group (AMARG) for inspection of levels of corrosion and fatigue.

In 2007 the Air Force requested information on the Airbus A380 freighter for possible use as a military transport to supplement the U.S. strategic airlift fleet.

The U.S. Air Force began to receive refitted C-5M aircraft in December 2008; full production of C-5Ms began in the summer of 2009. In 2009, the Congressional ban on the retirement of $\mathrm{C}-5 \mathrm{~s}$ was overturned. The Air Force seeks to retire one C-5A for each 10 new $\mathrm{C}-17$ s ordered.

The C-5A is the original version of the C-5. From 1969 to 1973,81 C-5As were delivered to U.S. Air Forces bases. Due to cracks found in the wings in the mid-1970s, the cargo weight was restricted. To restore the plane's full capability, the wing structure was redesigned. A program to install new strengthened wings on 77 C-5As was conducted from 1981 to 1987. The redesigned wing made use of a new aluminum alloy that did not exist during the original production.

The C-5B is an improved version of the C-5A. It incorporated all modifications and improvements made to the C-5A with improved wings, upgraded TF-39-GE-1C turbofan engines and updated avionics. From 1986 to 1989, 50 of the new variant were delivered to the U.S. Air Force.

The $\mathrm{C}-5 \mathrm{C}$ is a specially modified variant for transporting large cargo. Two C-5s (68-0213 and 680216) were modified to have a larger internal cargo capacity to accommodate large payloads, such as satellites for use by NASA. The major modifications were the removal of the rear passenger compartment floor, splitting the rear cargo door in the middle and installing a new movable aft bulkhead further to the rear. Modifications also included adding a second inlet for ground power, which can feed any power-dependent equipment that may form part of the cargo. The two C-5Cs are operated by U.S. Air Force crews on the behalf of NASA and are stationed at Travis AFB, California. 68-0216 completed the Avionics Modernization Program in January 2007.

Based on a recent study showing $80 \%$ of the $\mathrm{C}-5$ airframe service life remaining, AMC began an aggressive program to modernize all remaining $\mathrm{C}-5 \mathrm{Bs}$ and C-5Cs and many of the C-5As. The C-5 Avionics Modernization Program (AMP) began in 1998 and includes upgrading avionics to Global Air Traffic Management compliance, improving communications, new flat panel displays, improving navigation and safety equipment and installing a new autopilot system. The first flight of the first modified C-5 with AMP (85-0004) occurred on 21 December 2002.

Another part of the plan is a comprehensive Reliability Enhancement and Re-engining Program (RERP), which includes new General Electric CF6-80C 2 engines, pylons and auxiliary power units, with upgrades to aircraft skin and frame, landing gear, cockpit and the pressurization system. The CF6 engine produces $22 \%$ 
more thrust (for $50,000 \mathrm{lbf} / 220 \mathrm{kN}$ total from each engine) than existing C-5 engines, which will result in a $30 \%$ shorter takeoff roll, a $38 \%$ higher climb rate to initial altitude, a significantly increased cargo load and a longer range between refueling. The C-5s that complete these upgrades are designated C-5M Super Galaxy.

The C-5 AMP and RERP modernization programs plan to raise the mission-capable rate to a minimum goal of $75 \%$. Over the next 40 years, the U.S. Air Force estimates the C-5M will save over $\$ 20$ billion. The first C-5M conversion was completed on 16 May 2006 and performed its first flight on 19 June 2006. C-5Ms have been in flight testing out of Dobbins Air Reserve Base since June 2006. Test aircraft include a distinctively colored nose boom to acquire flight data.

The USAF decided to convert remaining C-5Bs and $\mathrm{C}-5 \mathrm{Cs}$ into $\mathrm{C}-5 \mathrm{Ms}$ with avionics upgrades and reengining in February 2008. The C-5As will receive only the avionics upgrades. The three test C-5Ms successfully completed developmental flight testing in August 2008. The test aircraft will begin Operational Test and Evaluation in September 2009. The RERP upgrade program is to be completed in 2016 .

Lockheed Martin announced that a C-5M test flight on 13 September 2009, set 41 new records. The flight's data have been submitted to the National Aeronautic Association for formal acceptance. The C-5M carried a payload of $176,610 \mathrm{lb}(80,110 \mathrm{~kg})$ to over $41,100 \mathrm{ft}$ $(12,500 \mathrm{~m})$ in $23 \mathrm{~min}, 59 \mathrm{sec}$. The flight set 33 times to climb records at various payload classes and broke the world record for the greatest payload to 6,562 feet $(2,000$ meters). The aircraft used for this flight had a takeoff weight of $649,680 \mathrm{lb}(294,690 \mathrm{~kg})$, which included a payload, fuel and crew.

A total of $52 \mathrm{C}-5 \mathrm{~s}$ is contracted to be modernized, consisting of $49 \mathrm{~B}-$, two C- and one A-model aircraft through the Reliability Enhancement and Re-Engining Program (RERP). Over 70 changes and upgrades are incorporated in the program, including newer, quieter, General Electric engines which increase reliability and make the Super Galaxy 10 percent more fuel efficient than legacy C-5s. Five C-5M Super Galaxies have been produced.

Lockheed also planned a civilian version of the C-5 Galaxy, the L-500, the company designation also used for the C-5 itself. Both passenger and cargo versions of the L-500 were designed. The all-passenger version would have been able to carry up to 1,000 travelers, while the all-cargo version was predicted to be able to carry typical C-5 volume for as little as 2 cents per tonmile (in 1967 dollars). Although some interest was expressed by carriers, no orders were placed for either L500 version, due to operational costs caused by low fuel efficiency, a significant concern for a profit-making carrier, even before the oil crises of the 1970s, keen competition from Boeing's 747 and high costs incurred by Lockheed in developing the C-5 and later, the L-1011 which led to the governmental rescue of the company.

There have been five C-5 Galaxy aircraft lost in crashes along with two class-A losses resulting from ground fire and one loss resulting from damage sustained on the ground. There have been at least two other C-5 crashes that resulted in major airframe damage, but the aircraft was repaired and returned to service.

On 27 May 1970, C-5A serial number 67-0172 was destroyed during a ground fire at Palmdale, California after an Air Turbine Motor (ATM) started backward and quickly overheated, setting the hydraulic system on fire and quickly consuming the aircraft. The engines were not running at the time of the fire. Five crew escaped, but seven firefighters suffered minor injuries fighting the blaze.

On 17 October 1970, C-5A S/N 66-8303 was destroyed during a ground fire at Marietta, Georgia. The fire started during maintenance in one of the aircraft's 12 fuel cells. One worker was killed and another injured. This was the first C-5 aircraft produced.

On 27 September 1974, C-5A 68-0227 crashed after over-running the runway at Clinton, Oklahoma Municipal Airport during an emergency landing following a serious landing gear fire. The crew mistakenly aligned the aircraft for the visual approach into the wrong airport, landing at Clinton Municipal Airport, which has a 4,400 ft $(1,300$ m) runway-instead of Clinton-Sherman airfield, which has a $13,500 \mathrm{ft}(4,100 \mathrm{~m})$ runway. This was the first operational loss of a C-5 Galaxy.

On 4 April 1975, C-5A 68-0218 crashed while carrying orphans out of Vietnam (Operation Baby Lift). This crash, known as Tan Son Nhut C-5 accident, is one of the most well known C-5 accidents to date. The crash occurred while trying to make an emergency landing at Tan Son Nhut Air Base Saigon, following a door lock failure in flight. 144 adults and children (including 76 babies) were killed out of the 305 board ( 243 children, 44 escorts, 16 crewmen and two flight nurses). Use of the C-5 was heavily restricted for several months due to this high profile incident.

On 31 July 1983, C-5A 70-0446 crashed on landing at Shemya, Alaska. The C-5 approached below the glide slope, hit an embankment short of the runway and bounced back into the air before coming to rest on the runway. Structural damage was extensive and the two aft main landing gear bogies were sheared from the airplane. There were no fatalities. A joint USAF/Lockheed team made repairs enabling a one-time ferry flight from Shemya to the Lockheed plant in Marietta, Georgia. There, the airplane was quickly christened Phoenix II and permanent repair efforts got underway. In addition to the structural repairs, Phoenix II also received an improved landing gear system (common to the then-new C-5B), wing modification and a color weather radar upgrade. The airplane was returned to service and was transferred to the Texas Air National Guard. 
In July 1985, C-5A 68-0216 landed wheels (gear) up at Travis Air Force Base, California. There were no injuries. The accident occurred while the crew was performing touch-and-go landings and did not lower the landing gear during the final approach of the day. The aircraft received significant damage to the lower fuselage and main landing gear pods. The $\mathrm{C}-5 \mathrm{~A}$ was later flown to Marietta for repairs. While there, the aircraft was selected to be the first C-5A converted to the C-5C configuration.

On 29 August 1990, C-5A 68-0228 crashed following an engine failure shortly after take-off. The aircraft took off from Ramstein Air Base in Germany in support of Operation Desert Shield. It was flown by a nine-member reserve crew from the 68th Airlift Squadron, 433rd Airlift Wing based at Kelly AFB, Texas. As the aircraft started to climb off the runway, one of the thrust reversers suddenly deployed. This resulted in a loss of control of the aircraft and the subsequent crash. Of the 17 people on board, only four survived the crash. All four were in the rear troop compartment. The sole crew member to survive, Staff Sgt. Lorenzo Galvan, Jr., was awarded the Airman's Medal for his actions in evacuating the survivors from the wreckage.

On 3 April 2006, C-5B 84-0059 crashed after an inflight emergency involving an indication that a thrust reverser was not locked. The C-5B assigned to the 436th Airlift Wing and flown by a reserve crew from the 709th Airlift Squadron, 512th Airlift Wing crashed about 2,000 $\mathrm{ft}(610 \mathrm{~m})$ short of runway 32 , while attempting a heavyweight emergency landing at Dover Air Force Base, Delaware. The airplane, carrying 17 people, had taken off from Dover about 21 min earlier and reported an in-flight emergency (number two engine thrust reverser not locked indication) $10 \mathrm{~min}$ into the flight. All 17 aboard survived, but two received serious injuries. The Air Force's accident investigation concluded the crash was a result of human error, most notably that the crew kept one of the functioning engines in flight idle while manipulating the throttle of the (dead) number two engine as if it was still running, while having the number three engine at idle, an error that was further amplified by the crew's decision to use a high flap setting that increased drag beyond normal two engine performance capabilities. The forward fuselage will be converted into a C-5 AMP avionics test bed and the rest of the airframe has been scrapped.

\section{Conclusion}

In this study, the authors want to present a few more distinct aircraft from a constructive and functional point of view.

Their role has often been determined by the need to achieve or fulfill certain more or less strategic objectives.

Such ships will also be built in the future more and more often in order to be able to respond to all new flight requirements and to meet, under optimal conditions, the new and increasingly demanding requirements.

Many of the new special aircraft have been built so far to achieve special tasks, or at the request of the defense ministry in some highly developed countries, even with the United States of America.

\section{Acknowledgement}

We acknowledge and thank Mr Taher M. AbuLebdeh, Associate Prof at North Carolina A and T State Univesity, United States and Mr Muftah H. El-Naas PhD MCIC FICCE QAFCO Chair Professor in Chemical Process Engineering Gas Processing Center College of Engineering Qatar University and Ms Shweta Agarwala, Senior Research Scientist at Singapore Center for 3D Printing Nanyang Technological University Singapore for their suggestions and comments. The Authors acknowledge Liquid Metals Technologies Inc, Ca USAthat kindly supply the samples for the characterization and Dr Francesco Tatti (FEI Company Application Specialist SEM-SDB) for its contribut in the preparation of this paper experiments and analyses. The authors would like to appreciate the facilities and assistance provided by the Advanced Technology Dental Research Laboratory, Faculty of dentistry, King Abdul Aziz University. The authors would also appreciate the research technicians, Basim Al Turki and Fahad Al Othaibi for their cooperation.

\section{Author's Contributions}

All the authors contributed equally to prepare, develop and carry out this manuscript.

\section{Ethics}

This article is original and contains unpublished material. The corresponding author confirms that all of the other authors have read and approved the manuscript and no ethical issues involved.

\section{References}

Aversa, R., R.V.V. Petrescu, A. Apicella and F.I.T. Petrescu, 2017a. Nano-diamond hybrid materials for structural biomedical application. Am. J. Biochem. Biotechnol.

Aversa, R., R.V. Petrescu, B. Akash, R.B. Bucinell and J.M. Corchado et al., 2017b. Kinematics and forces to a new model forging manipulator. Am. J. Applied Sci., 14: 60-80.

Aversa, R., R.V. Petrescu, A. Apicella, I.T.F. Petrescu and J.K. Calautit et al., 2017c. Something about the $\mathrm{V}$ engines design. Am. J. Applied Sci., 14: 34-52.

Aversa, R., D. Parcesepe, R.V.V. Petrescu, F. Berto and G. Chen et al., 2017d. Process ability of bulk metallic glasses. Am. J. Applied Sci., 14: 294-301. 
Aversa, R., R.V.V. Petrescu, B. Akash, R.B. Bucinell and J.M. Corchado et al., 2017e. Something about the balancing of thermal motors. Am. J. Eng. Applied Sci., 10: 200.217. DOI: 10.3844/ajeassp.2017.200.217

Aversa, R., F.I.T. Petrescu, R.V. Petrescu and A. Apicella, 2016a. Biomimetic FEA bone modeling for customized hybrid biological prostheses development. Am. J. Applied Sci., 13: 1060-1067. DOI: 10.3844/ajassp.2016.1060.1067

Aversa, R., D. Parcesepe, R.V. Petrescu, G. Chen and F.I.T. Petrescu et al., 2016b. Glassy amorphous metal injection molded induced morphological defects. Am. J. Applied Sci., 13: 1476-1482.

Aversa, R., R.V. Petrescu, F.I.T. Petrescu and A. Apicella, 2016c. Smart-factory: Optimization and process control of composite centrifuged pipes. Am. J. Applied Sci., 13: 1330-1341.

Aversa, R., F. Tamburrino, R.V. Petrescu, F.I.T. Petrescu and M. Artur et al., 2016d. Biomechanically inspired shape memory effect machines driven by muscle like acting NiTi alloys. Am. J. Applied Sci., 13: 1264-1271.

Aversa, R., E.M. Buzea, R.V. Petrescu, A. Apicella and M. Neacsa et al., 2016e. Present a mechatronic system having able to determine the concentration of carotenoids. Am. J. Eng. Applied Sci., 9: 1106-1111.

Aversa, R., R.V. Petrescu, R. Sorrentino, F.I.T. Petrescu and A. Apicella, 2016f. Hybrid ceramo-polymeric nanocomposite for biomimetic scaffolds design and preparation. Am. J. Eng. Applied Sci., 9: 1096-1105.

Aversa, R., V. Perrotta, R.V. Petrescu, C. Misiano and F.I.T. Petrescu et al., 2016g. From structural colors to super-hydrophobicity and achromatic transparent protective coatings: Ion plating plasma assisted $\mathrm{TiO}_{2}$ and $\mathrm{SiO}_{2}$ Nano-film deposition. Am. J. Eng. Applied Sci., 9: 1037-1045.

Aversa, R., R.V. Petrescu, F.I.T. Petrescu and A. Apicella, 2016h. Biomimetic and evolutionary design driven innovation in sustainable products development. Am. J. Eng. Applied Sci., 9: 1027-1036.

Aversa, R., R.V. Petrescu, A. Apicella and F.I.T. Petrescu, 2016i. Mitochondria are naturally micro robots-a review. Am. J. Eng. Applied Sci., 9: 991-1002.
Aversa, R., R.V. Petrescu, A. Apicella and F.I.T. Petrescu, 2016j. We are addicted to vitamins $\mathrm{C}$ and E-A review. Am. J. Eng. Applied Sci., 9: 1003-1018.

Aversa, R., R.V. Petrescu, A. Apicella and F.I.T. Petrescu, 2016k. Physiologic human fluids and swelling behavior of hydrophilic biocompatible hybrid ceramo-polymeric materials. Am. J. Eng. Applied Sci., 9: 962-972.

Aversa, R., R.V. Petrescu, A. Apicella and F.I.T. Petrescu, 20161. One can slow down the aging through antioxidants. Am. J. Eng. Applied Sci., 9: 1112-1126.

Aversa, R., R.V. Petrescu, A. Apicella and F.I.T. Petrescu, 2016m. About homeopathy or «Similia similibus curentur 》. Am. J. Eng. Applied Sci., 9: 1164-1172.

Aversa, R., R.V. Petrescu, A. Apicella and F.I.T. Petrescu, 2016n. The basic elements of life's. Am. J. Eng. Applied Sci., 9: 1189-1197.

Aversa, R., F.I.T. Petrescu, R.V. Petrescu and A. Apicella, 2016o. Flexible stem trabecular prostheses. Am. J. Eng. Applied Sci., 9: 1213-1221.

Mirsayar, M.M., V.A. Joneidi, R.V.V. Petrescu, F.I.T. Petrescu and F. Berto, 2017 Extended MTSN criterion for fracture analysis of soda lime glass. Eng. Fracture Mechanics 178: 50-59. DOI: 10.1016/j.engfracmech.2017.04.018

Petrescu, R.V. and F.I. Petrescu, 2013a. Lockheed Martin. 1st Edn., CreateSpace, pp: 114.

Petrescu, R.V. and F.I. Petrescu, 2013b. Northrop. 1st Edn., CreateSpace, pp: 96.

Petrescu, R.V. and F.I. Petrescu, 2013c. The Aviation History or New Aircraft I Color. 1st Edn., CreateSpace, pp: 292.

Petrescu, R.V. and FIT. Petrescu, 2012a. Northrop. Books on Demand, ISBN-13: 978-3848209323, pp: 142.

Petrescu, F.I. and R.V. Petrescu, 2012b. New Aircraft II. 1 st Edn., Books on Demand, pp: 138.

Petrescu, F.I. and R.V. Petrescu, 2011. Memories About Flight. 1st Edn., CreateSpace, pp: 652.

Petrescu, F.I.T., 2009. New aircraft. Proceedings of the 3rd International Conference on Computational Mechanics, Oct. 29-30, Brasov, Romania. 